\section{Zoran Simonovic}

Institute for Agricultural Economics, Belgrade

\section{Dejan Petrovic ${ }^{2}$}

University of Belgrade,

Faculty of Organizational Sciences

\section{Nikola Curcic ${ }^{3}$}

Institute for Agricultural Economics, Belgrade
ORIGINAL SCIENTIFIC ARTICLE doi:10.5937/ekonomika1904011S Received: November, 14. 2019. Accepted: December, 09. 2019.

\title{
PRODUCTION OF GRAPES AND WINE IN SERBIA ${ }^{4}$
}

\begin{abstract}
Grape and wine production in Serbia is one of the significant branches of agricultural production. Grapes and wine produced in Serbia have for many years a reputation of good quality products. Grapes and wine are recognizable agricultural products that market well in the international market. The consequences of the transition have left their mark on the production of wine in Serbia. The old agricultural combines were sold, or simply ceased to operate, and as a result, a several of well-known winemaking brands ceased to exist. From 2000 onwards, a new trend has emerged, that is, the formation of small private wineries in Serbia. They become the backbone in wine production. We have just paid attention to them in this paper. We believe that small wineries will be the backbone of wine production. For this reason, we conducted a survey to ask the producers themselves what problems they encountered with organizing the production, the association for the sake of easier placement of wine, as well as the sale of their products.
\end{abstract}

Key words: grapes, wine, wineries, consumption, production, Serbia.

JEL classification: Q11, Q13,Q17

\section{ПРОИЗВОДЊА ГРОЖТА И ВИНА У СРБИЈИ}

\section{Апстракт}

Производна грожђа и вина у Србији представљь једну од значајних грана пољопривредне производюе. Грожће и вино произведено у Србији има већ дуги низ година репутацију производа доброг квалитета. Грожђе и вино су препознатьиив пољопривредни производи који се добро пласирају на међународном тржишту. Последице транзиије оставиле су трага и на

\footnotetext{
${ }^{1}$ zoki@medianis.net

${ }^{2}$ petrovic.dejan@fon.bg.ac.rs

3 nikolavcurcic@yahoo.com

${ }^{4}$ This paper is part of the research project , Sustainable agriculture and rural development in the function of accomplishing strategic objectives of the Republic of Serbia within the Danube region ", No. 46006, financed by the Ministry of Education, Science and Technological Development of the Republic of Serbia.
} 
производюу вина у Србији. Стари полопривредни комбинати су продати, или су једноставно престали да раде и због тога је читав низ до тада познатих брендова у винарству престао да постоји. Од 2000. године па надале долази до новог тренда, односно до бормираюа малих приватних винарија у Србији. Оне постају окосница у производни вина. Ми смо у овом раду управо посветили пажну ғима. Сматрамо да ће мале винарије бити окосница у производни вина. Из тог разлога ми смо урадили анкету да би смо питали саме произвођаче на које проблеме наилазе у организовану производюе, удруживану због такшег пласмана вина, као и самој продаји својих производа.

Кључне речи: грожђе, вино, винарије, конзумација, производюа, Србија

\section{Introduction}

Due to its geographical location, climatic and soil factors, the conditions for growing grapevines in Serbia provide opportunities for the production of different types of wine. From the north to the south, there are vineyards characterized by diversity. Many regions have gained a very rich tradition in wine production, and as such, are well known in Serbia and in the foreign market.

As a result of sanctions and transition, vineyards reduced in the late twentieth and early 21 st centuries. According to the Statistical Office of the Republic of Serbia, vineyards in Serbia have been reduced 70,634 hectares to about 22.150 hectares by the last decade. This should be emphasized because in the 1980s, under vineyards in Serbia, there were 100,000 hectares (Republic Bureau of Statistics, 1998). The second trend, which characterized the first decade of the 21 st century, is the formation of a significant area with modern assortment, as well as with varieties adapted to our conditions. It is necessary to point out that the establishment of new wineries and wine cellars, which is characterized by quality planted grapes and the production of high quality wines. It is expected that if Serbia manages to restore several thousand hectares of vineyards over the next seven to ten years, with continued state support and good development policies, wine production and exports can increase significantly. (Petrovic, et all, 814).

According to the Statistical Office of the Republic of Serbia, , in the period 2006-2014, exports of wine and other spirits produced based on grapes and more than doubled to EUR 17 million. This is a significant shift from 2006 years when exports amounted to only $€ 7$ million.

The biggest problem for small wine producers is the fact that only those producers who accept state planting varieties have access to subsidies. In the case of traditional varieties, only the individual varieties by subsidized, and most of the traditional types are absent, which puts the producers of those varieties at a disadvantage. Family farms usually deal with indigenous varieties of the region, eliminating them from the subsidy system at the outset. The second biggest problem is administrative difficulties. They produce a very small number of bottles compared to large manufacturers, so the fixed costs per bottle are higher than the costs of large manufacturers. The third problem raised by the producers is that there are no laboratories for the propagation of autochthonous varieties and therefore it is difficult to increase the area under vines. (Lajko, Erdelj, 290).

If the demand for wine continues to grow, there is an opportunity for the EU to introduce incentive measures instead of controlling wine production. This assistance 
would be extremely important to Serbia. She would then be able to reconstruct her previously built system and increase the areas under the vine. Serbia currently exports small quantities of wine, ranked 40th on the list of wine exporters. In addition, although according to statistics, Serbian residents consume wine in small quantities, the amount of wine imports still exceeds the level of exports. (Lajko, Erdelj, 301).

Viticulture production still has a modest annual share in the total value of agricultural production of only a few percent, recently the deficit in foreign trade is explained by the growing trend of domestic wine consumption. In our further presentations, we have decided to look at small and medium-sized manufacturers who are struggling to market their products.

\section{Wine production in Serbia}

Wine is always associated with grapes, but wine and grapes do not match each other, which means that tasty grapes do not produce good wine. This is why fine wines are made from grape varieties that are not very good to eat. Wines are usually classified according by production method (common wines, special wines and distillation wines); color (white, rose and red); quality depending on the chemical composition and tasting value (table wine, table wine with registered geographical origin, quality wines with registered geographical origin, premium wines with registered geographical origin) 16; unfermented sugar content (dry, semi-dry, semi-dry and sweet wines); purpose and use value (special, sparkling and pradikats of wine); age (young, old, very old and archival wines). (Vlahovic et all). In Table 1, we have produced grape production of 1000 tonnes in Serbia and some Western Balkan countries.

In Table 1, we can see that the largest producers in the region are Northern Macedonia and Albania. Serbia is in third place. The output of all manufacturers varies from year to year and is mostly weather dependent.

Table 1. Grape production in the Western Balkan countries (in 000 tonnes)

\begin{tabular}{|l|r|r|r|r|r|}
\hline Wine & \multicolumn{1}{|c|}{2013} & \multicolumn{1}{|c|}{2014} & \multicolumn{1}{|c|}{2015} & \multicolumn{1}{c|}{2016} & \multicolumn{1}{c|}{2017} \\
\hline Serbia & $\mathbf{2 0 0 , 0}$ & $\mathbf{1 1 2 , 5}$ & $\mathbf{1 7 0 , 6}$ & $\mathbf{1 4 5 , 8}$ & $\mathbf{1 6 5 , 6}$ \\
\hline Montenegro & 24,1 & 17,1 & 23,1 & 28,9 & 22,2 \\
\hline N. Macedonia & 292,1 & 159,9 & 324,8 & 333,3 & 180,3 \\
\hline BiH & 31,8 & 26,2 & 32,8 & 36,9 & 28,0 \\
\hline Albania & 204,0 & 203,7 & 205,0 & 205,1 & 202,9 \\
\hline
\end{tabular}

Source: Statistical Office of the Republic of Serbia (Economic Accounts for Agriculture in the Republic of Serbia 2007-2016). MONSTAT, SSO (Statistical Yearbooks), Agency of Statistics of $\mathrm{BH}$, Ministry of Agriculture, Food and Consumer Protection (Statistical Yearbooks).

On the territory of the Republic of Serbia (excluding AP Kosovo and Metohija), there is 22,150 ha under the vine. They are cultivated by 80,445 farms, of which 27,224 own less than 10 acres, which indicates the fragmentation of the parcels and, consequently, the production ( 0.275 ha of the size of the average vineyard). Wine varieties are grown on 17,483 ha ( $75 \%$ per acre), while fresh varieties are grown on 4,667 ha ( $24.3 \%$ acreage). 
There are 975 family holdings on the territory of Topola municipality, which own vineyards on an area of 469 ha. (Denda, 85) The largest share is for eating varieties (318 ha), and almost equally common wine varieties ( $88 \mathrm{ha}$ ) and varieties with geographical origin (63 ha) (RZS, 2013a).

Depending on the geographical but climatic conditions, we can say that the territory of Serbia is divided into three regions: Vojvodina, Central Serbia, and Kosovo, and Metohija. Within them, 22 areas and as many as 77 vineyards, with a large number of vineyard oases have been single out. Small wineries and cellars, which have been opening a lot by up the last single years, we can say freely that they inherit the former state-owned large wineries. In that sense, we can say that, by bottle design, placement and especially taste, wines at the territory of Serbia do not lag behind the North Macedonian, French, Italian and Spanish, and wines of many other renowned producers to many other countries at the world. The territory of Serbia is covered with hilly terrains, which are mostly exposed to the sun throughout the year and are therefore very suitable for growing vines. The grapes from these grounds are of excellent quality. What we would like to emphasize is that wine production of the territory of Serbia has a very rich tradition, dating from Roman times.

Many regions of Serbia produce their own special wines From the region of Vojvodina, through central Serbia to the southern regions, we find a variety of grapes and wines produced in these regions. In that sense, different types of wine are produced in Serbia by the north to the south. Of white wines, these are, first and foremost, Italian Riesling wines, Muscat wilt, Muscat croc, Semi, Sauvignon, Green Sylvanian, Traminer, Banat Riesling, Buvi, Slanamenka, Smederevka and Chassell, and partly Kevedinka. Of red wines are present burgundy, game, Merlo, redemption, and frank.

One of the vineyards of central Serbia, whose wine symbolizes the entire area, is Zupa with its small but very beautiful town of Aleksandrovac. Zupa is a wine-growing area in our country that can rightly be said to be Serbian Burgonja. Parish red wine and parish rose have been successfully presenting Serbia, both domestically and internationally. Typical wines of this area are red wine, parish rose, and white bile.

In the valley of the Morava River, from Stalac to Nis, there are the Aleksinac and Nis wine-growing areas. This is a predominantly white table wine, known as "noble". This wine does not come from the grape variety of the same name, but rather it is a standard type of wine made from rennet and buoyancy. In the area of Nis, there are several small vineyard centers known for their wines, such as the surroundings of Matejevac, Malče, Kamenica, and especially Sićevo.

East of Nis is the Knjazevac, vineyard known for its wines both red and white, quality and ordinary table wines. The Knjazevac production red wine of game varieties and black burgundy rose wine called Muscat Hamburg is well known to the market. These are wines with very good color, pronounced varietal bouquet, and very pleasant taste.

Among the regional wines, the wine called "Dubravka" is especially notable. Drawing on a rich tradition in the past, landscape wines have gained a high reputation, which is still on the market today. With Negotin, as the center of this large area, we should mention other smaller ones, but very significant, such as in the vicinity of Rogljevo and Rajac, then the one beside the Danube around Mihajlovac and Kladovo.

Among the regional wines, red wines of the varieties: Prokupac, Game, and Black Burgundy have gained a great reputation. To ensure the good color of these wines, a spice 
variety is cultivated in this area, as a coloring agent.

Even the white wines of this vineyard are not far behind the black ones. Until recently, wines of the bargain variety, golden yellow, and distinctive bouquet stood out among these wines.

However, there is less of this Krajina wine today, but it has mostly remained in Roglje and Raja.

In addition to red and white wines, Krajina produces wines of the type known by this region.

Southwest of Niš on the left side of the South Morava River, there are vineyards of the Toplica vineyards with the town of Prokuplje.

Along the South Morava on its right, there are vineyards of Vlasotinac, Leskovac and Vranje vineyards. White table wine of the breeding type is also produced in this area. This area is also characterized by a relatively large share of the Plovdiv variety, which, together with the buyer, dominates wine production.

In terms of red wine production, Vlasotince is more prominent with one type known as "thunder".In the area of Kosovo and Metohija, at the foot of the great mountain massifs of Šara, Koritnik, Pashtrik, Prokletije and Žleb, hilly terrain contains vineyards. Among the red wines of the area, the "Kosovo Peony" is particularly well known. (http:// www.zdravasrbija.com/Zemlja/Vinogradarstvo/116-Grozdja-i-vina-Srbije.php).

\section{Sales and wine consumption in Serbia}

Research on wine sales channels shows that large retail chains generally offer a large assortment of imported wines of different quality and local wines of lower and medium quality. However, there are very few quality local wines lately included in the offer. Most retail outlets, generally small shops, are poorly stocked with wines, mostly those of low quality. The most important distributors of high quality Serbian wines are shops and restaurants. Wine boutiques are owned by some wine producers and consist of their own and sometimes imported wines. (Salai et all, 109).

According to the economic accounts for agriculture, the production of wine at producer prices, which in millions of euros, is given only for Serbia and Northern Macedonia in Table 2. For other Western Balkan countries we did not find this data. Wine prices vary from year to year. According to the data in the table, wine production has increased in the last observed year.

Table 2. Production of wine at producer prices (in millions of euros)

\begin{tabular}{|l|r|r|r|r|r|}
\hline Wine & \multicolumn{1}{|c|}{2012} & \multicolumn{1}{|c|}{2013} & \multicolumn{1}{c|}{2014} & \multicolumn{1}{c|}{2015} & \multicolumn{1}{c|}{2016} \\
\hline Serbia & 167,3 & 243,4 & 295,1 & 188,8 & 313,3 \\
\hline N. Macedonia & 38,1 & 51,0 & 43,8 & 64,2 & 50,5 \\
\hline
\end{tabular}

Source: Statistical Office of the Republic of Serbia (Economic Accounts for Agriculture in the Republic of Serbia 2007-2016). SSO (Statistical Yearbooks)

Wine culture is defined as the cultivated, refined and civilized consumption of wine, which is not measured by the amount of wine drunk but gaining knowledge and procedures in the field of viticulture, wine production, and catering. Very often, a combination of food and wine makes a meal a unique gastronomic experience, while respecting the rule that 
no wine cannot be combined with a particular meal, and enjoying a good wine from a connoisseur is always a solemn ceremony. The dominant part of the population in Serbia considers themselves consuming wine, so although wine is placed in a group of alcoholic beverages, by tradition and customs, it is often on the tables in many homes along with brandy and beer. (Vlahovic et al, 40). The best evidence for this claim is Serbia's share in total wine consumption, which is about 1 million hectoliters of wine a year on average (Table 3 ).

Table 3. World's major wine consumers (in millions of hl)

\begin{tabular}{|l|r|r|r|r|r|}
\hline & \multicolumn{2}{|c|}{2014} & \multicolumn{1}{|c|}{2015} & \multicolumn{1}{c|}{2016} & \multicolumn{1}{c|}{2018} \\
\hline USA & 30,6 & 30,9 & 31,7 & 32,6 & 33,0 \\
\hline France & 27,5 & 27,3 & 27,1 & 27,0 & 26,8 \\
\hline Italy & 19,5 & 21,4 & 22,4 & 22,6 & 22,4 \\
\hline Germany & 20,3 & 20,5 & 20,2 & 19,7 & 20,0 \\
\hline China & 17,4 & 18,1 & 19,2 & 19,3 & 17,6 \\
\hline UK & 12,6 & 12,7 & 12,9 & 12,7 & 12,4 \\
\hline Russian & 11,1 & 10,8 & 10,5 & 11,1 & 11,9 \\
Federation & 9,8 & 9,8 & 9,9 & 10,5 & 10,5 \\
\hline Spain & 9,9 & 10,3 & 9,4 & 8,9 & 8,4 \\
\hline Argentina & 5,4 & 5,5 & 5,4 & 5,9 & 6,0 \\
\hline Australia & 4,7 & 4,0 & 3,8 & 4,1 & 4,5 \\
\hline Romania & 4,0 & 4,3 & 4,4 & 4,5 & 4,3 \\
\hline South Africa & 3,2 & 3,3 & 3,1 & 3,3 & 3,3 \\
\hline Brazil & 2,6 & 2,4 & 2,3 & 2,3 & 2,1 \\
\hline Greece & 1,2 & 1,1 & 1,2 & 1,1 & 1,1 \\
\hline Croatia & 1,1 & 1,0 & 1,0 & 1,1 & 1,1 \\
\hline Serbia & 0,9 & 1,0 & 1,0 & 0,9 & 1,0 \\
\hline Bulgaria & & & & & \\
\hline World & & & & & \\
\hline
\end{tabular}

Source: http://www.oiv.int/public/medias/6782/oiv-2019-statistical-report-on-worldvitiviniculture.pdf

\section{Research related to wine production}

The research was conducted with the main aim to look at the factors that determine the state of wine production in Serbia, as well as to present the general problems of domestic wine producers. To show the current state of the grape and wine production in Serbia, we have done a research, which concerned primarily wine producers. With the research we wanted to look at the current state of business, but also to see if there are opportunities for improving the work of wineries and cellars.

The method used is a survey based on a previously prepared application, made on a sample of 103 wineries from the territory of Serbia. Despite the number of questionnaires, into a relatively limited sample, the answers obtained are, in our opinion, indicative enough to be the basis for highlighting the primary factors in wine production in the Republic.

The document contains, in addition to internal documentation, all other available data sources (official statistics and actual literature). Data processing and data analysis based on standard statistical and mathematical methods. 
In the 2019 survey, we included 103 wineries. A large number of questionnaires were completed by the authors themselves. During the filling in the interview was conducted with the interviewed persons. In this way, the authors became acquainted with the condition of the means of work, objects, plantings, etc. Thus, in addition to the survey method, the interview method (interview as a method of direct observation and insight into the work of wineries) was also represented in a far smaller case. Of course, this method was represented in only a few cases.

The first question is: Does your winery belong to a cooperative or a farmer's association? We received the following answers:

Table 4. Affiliation to a cooperative or farmer's association

\begin{tabular}{|l|r|}
\hline respondents of the respondents & participation in \% \\
\hline yes & 52,43 \\
\hline no & 42,72 \\
\hline no answer & 4,85 \\
\hline total $\mathrm{n}=103$ & 100,0 \\
\hline
\end{tabular}

Source: Calculation of the author based on the survey

Almost half of the winery owners surveyed are members of an association with their area. To the surveyed producers that are members of an association, we asked which association or cooperative they belong to. We have received a list of a large number of associations. One gets the impression that all these associations by a small number of members. This is probably also their main problem when performing in the market. Members of the following associations were surveyed:

- Association of Serbian Winegrowers and Winemakers (51 winemakers and established producers).

- Sumadija Winemakers Association (17 wineries).

- Belgrade Wineries (14 wineries).

- Association of Producers of Grape and Wine with Geographical Indication Srem - Fruska Gora (34 wineries).

- $\quad$ Small Winery Association (2 winemakers).

The association of grape and wine producers through cooperatives and other associations is diverse. The most affiliated manufacturers are located in Vojvodina and the City of Belgrade.

Nearly $40 \%$ of the surveyed members of the associations provided written comments in the survey when filling in, referring to the benefits in the same.

Table 5. Written comments on the benefits for membership of the winery association of only those wineries that belong to them

\begin{tabular}{|c|c|}
\hline respondents of the respondents & participation in $\%$ \\
\hline did not write & 37,86 \\
\hline wrote & 62,14 \\
\hline total $n=103$ & 100,0 \\
\hline
\end{tabular}

Source: Calculation of the author based on the survey 
About $15 \%$ of the surveyed members of the associations provided written comments in the survey when filling in, regarding the shortcomings therein.

Table 6. Written comments on the shortcomings for membership of only those wineries that belong to them

\begin{tabular}{|l|ll|}
\hline respondents of the respondents & participation in \% & \\
\hline did not write & & 85,44 \\
\hline wrote & & 14,56 \\
\hline total $\mathrm{n}=103$ & & 100,0 \\
\hline
\end{tabular}

Source: Calculation of the author based on the survey

Only 21 surveyed wineries answered this question why they are not members of an association. Other respondents did not consider answering this question because they are already members of an association.

Table 7. What are the reasons for not being a farmer's association or cooperative

\begin{tabular}{|c|c|}
\hline respondents of the respondents & participation in $\%$ \\
\hline they cannot realize significant benefits & 57,14 \\
\hline no association & 14,29 \\
\hline no cooperative & 19,05 \\
\hline something else & 14,29 \\
\hline total $n=21$ & 100,0 \\
\hline
\end{tabular}

Source: Calculation of the author based on the survey

When asked, How do you sell your products? Most of the wineries surveyed stated that they market their products directly to various sales chains and through their associations. Few sell directly at the market.

Table 8. Product sales methods

\begin{tabular}{|l|r|r|}
\hline respondents of the respondents & number of wineries & participation in \% \\
\hline through the association & 39 & 37,86 \\
\hline personally at the market & 6 & 5,83 \\
\hline enterprises & 6 & 0,97 \\
\hline through purchasers & 1 & 0,97 \\
\hline directly to sales chains & 1 & 49,51 \\
\hline total & 51 & 98,06 \\
\hline no answer & 101 & 4,85 \\
\hline total $\mathrm{n}=103$ & 5 & 100,0 \\
\hline
\end{tabular}

Source: Calculation of the author based on the survey

Concerning the greatest restrictions on wine production, the respondents responded as follows. (to over $50 \%$ of cases) cited financial reasons as the main problem to wine production, $(31 \%)$ stated that they had problems with placing wine on the market (11\%). Considers that because they did not belong to any association they had a problem with producing and selling wine. Just under (4\%) believe that support from the agrarian budget for this type of production should be improved. 
Table 9. Major restrictions on wine production

\begin{tabular}{|l|r|r|}
\hline respondents of the respondents & number of wineries & participation in \% \\
\hline placement & 32 & 31,07 \\
\hline financial resources & 56 & 54,37 \\
\hline not belonging to an association & 11 & 10,68 \\
\hline low support from the agrarian budget & 4 & 3,88 \\
\hline total $\mathrm{n}=103$ & 103 & 100,0 \\
\hline
\end{tabular}

Source: Calculation of the author based on the survey

\section{Conclusion}

If we look at the regions where grapes and wine produced, we can see that there is a great deal of variety between the regions. There are also many regions within these regions, each of which is unique. We believe that at this moment, that all regions have a chance to organizing productions into the agrarian business, i.e. in agrarian firms or to redefine the already acquired comparative advantages in their production. Of course, state support to organize such production would also be necessary at this stage by creating subsidy conditions that would be as similar as possible to those practiced in the EU.

Considering the trends in the EU market, but more broadly, taking into account the achieved level of production and competitiveness of domestic producers of grapes and wines, it can be concluded that, assuming that the quality control standards in the world market for grape and wine exports are met, it can only be competitive if it differentiates offer in terms of export of high quality products, with brand and indigenous origin marking.

The results of a research conducted with producers in the Republic of Serbia to the possibilities of organizing production indicate that there is an interest of local winemakers to improve their production, but also with the desire to market their products. It can be concluded that winemakers should more actively and more benefit from the benefits of association. Engaging winemakers in this direction would certainly help to increase the potential customers for the products they offer in the market.

\section{References}

Denda, S., \& Denda, B. (2016). Proizvodnja i robna razmena grožđa i vina: stanje u svetu i Srbiji (šumadijski region). Agroekonomika, 45(70), 81-93.

Livaja, T., Marašević, N., \& Zarić, V. (2018). Prodaja vina malih proizvođača mogućnosti i ograničenja. Zbornik savetovanja poljoprivrednika $i$ agronoma Srbije, 15 .

Jakšić, D., Ivanišević, D., Đokić, V., \& Brbaklić Tepavac, M. (2012). Vinski atlas. Republiĉki zavod za statistiku, Beograd, Srbija.

Jovanović, O., \& Zubović, J., (2019). The Importance of Subsidies for SME Development in the Agricultural Sector of Serbia, WBJAERD, Vol. 1, No. 1, 1-84. 
Lajko, B., \& Erdelji, T. (2015). The development strategy of the wine industry of Vojvodina in the global economic sphere. Anali Ekonomskog fakulteta u Subotici, (34), 289-308.

Mihailović, B., Simonović, Z., \& Cvijanović, D. (2008). Voćarsko-vinogradarska proizvodnja u Srbiji. Ekonomika, 54(5-6), 157-164.

Mojović, L., Pejin, D., Rakin, M., Pejin, J., Nikolić, S., \& Djukić-Vuković, A. (2012). How to improve the economy of bioethanol production in Serbia. Renewable and Sustainable Energy Reviews, 16(8), 6040-6047.

Overton, J., \& Murray, W. E. (2016). Investing in place: articulations and congregations of capital in the wine industry. The Geographical Journal, 182(1), 49-58.

Petković, G., Werner, M., \& Pindžo, R. (2019). Iskustvo putovanja - put rimskih imperatora i dunavski put vina. Ekonomika preduzeća, 67(1-2), 181-192.

Petrović, J., Krstić, B., \& Stanišić, T. (2015). Analiza proizvodnih potencijala i konkurentske pozicije Srbije na međunarodnom tržištu vina. Ekonomika poljoprivrede, 62(3), 813-829.

Salai, S., Gašović, M., \& Čelić, M. (2013). Marketing research into wine consumption determinants in Vojvodina. Marketing, 44(2), 103-114.

Sgroi, F., Di Trapani, A. M., Testa, R., \& Tudisca, S. (2014). Strategy to increase the farm competitiveness. Am. J. Agric. Biol. Sci, 9(3), 394-400.

Sredojević, Z., Svirčev, B., \& Peco, E. (2015). Rentabilnost ulaganja u podizanje i eksploataciju zasada vinograda kao izazov za investitore. Agroekonomika, Poljoprivredni fakultet u Novom Sadu, 44(68), 89-102.

Ruml, M., Vuković, A., Vujadinović, M., Djurdjević, V., Ranković-Vasić, Z., Atanacković, Z., ... \& Petrović, N. (2012). On the use of regional climate models: implications of climate change for viticulture in Serbia. Agricultural and forest meteorology, 158, 53-62.

Vlahović, B., Tomić, D., \& Puškarić, A. (2008). Proizvodnja vina u Republici Srbiji. Ekonomika poljoprivrede, Institut za ekonomiku poljoprivrede, Beograd, Srbija, 55(3), 277-288.

Vlahović, B., Potrebić, V., \& Jeločnik, M. (2013). Preferences of wine consumers on Serbian market (vol. 59, pg. 37, 2012). Ekonomika poljoprivrede, 60(3), 676-676.

Републички завод за статистику, (1998). Статистички годишњак. Београд.

RZS. (2013a). Poljoprivreda u Republici Srbiji I - popis poljoprivrede 2012. godine. Beograd: Republički zavod za statistiku.

http://www.zdravasrbija.com/Zemlja/Vinogradarstvo/116-Grozdja-i-vina-Srbije.php (25.11.2019).

http://www.oiv.int/public/medias/6782/oiv-2019-statistical-report-on-worldvitiviniculture.pdf (25.11.2019). 